\title{
EFFECT OF GONADOTROPHIN STIMULATION OF URINARY STEROID EXCRETION AFTER RELOCATION OF NORMAL AND CRYPTORCHID TESTES IN THE BOAR
}

\author{
R. M. LIPTRAP AND J. I. RAESIDE \\ Department of Biomedical Sciences, University of Guelph, \\ Guelph, Ontario, Canada
}

(Received 31st January 1972, accepted 28th March 1972)

It is well established that cryptorchidism is associated with degeneration of the seminiferous tubules, but there is less certain knowledge concerning the internal secretory capacity of the abdominal testis. Although unilaterally and bilaterally cryptorchid boars are able to excrete dehydroepiandrosterone (DHA) and oestrogens in amounts comparable to those of normal boars (Liptrap \& Raeside, 1970), the abdominal testes of such animals show a limited response to gonadotrophin stimulation (Liptrap \& Raeside, 1971). The purpose of the present study was to determine if the higher abdominal temperature was responsible, at least in part, for the limited response of the cryptorchid testis to stimulation by HCG, as reflected in the urinary excretion of DHA and oestrogens.

The breeding background of the cryptorchid Yorkshire pigs used in this study has been outlined by Fredeen \& Newman (1968). Collection of urine for 48-hr periods, or for 24-hr periods when daily treatment with 2000 i.u. HCG (Pregnyl; Organon Inc., Montreal) was administered, was carried out as previously described (Liptrap \& Raeside, 1971). The excretion values for DHA ( $3 \beta$-hydroxyandrost-5-en-17-one), which is of testicular origin in the boar (Huis in't Veld, Louwerens \& Reilingh, 1961), were determined as described by Raeside (1965). The results for total oestrogens in the urine samples were estimated with the procedure outlined by Raeside (1963). For convenience, all results are reported in $\mathrm{mg} / 24 \mathrm{hr}$. Statistical comparisons with control levels for each boar were made using Student's $t$ test (Snedecor, 1956).

In two normal boars, the cryptorchid condition was created surgically as outlined previously (Liptrap \& Raeside, 1970). Relocation of the abdominal testes of cryptorchid boars was accomplished surgically under pentobarbital sodium (Diabutal; Diamond Laboratories, Downsview, Ont.) anaesthesia. The abdominal testes were brought out through incisions made in each flank. The peritoneum and muscle layers were closed routinely, except for a small opening through which the spermatic vessels passed. A pocket for the testis was created by subcutaneous blunt dissection so that when the skin incision was closed, the testis lay between the muscle layers and the skin.

A summary of the values for DHA and oestrogen excretion during HCG 
stimulation before and after relocation of the testes is shown in Table 1. The values for a normal boar (3487) are also included at two ages which spanned the ages of the boars used in this study. A highly significant increase in urinary

TABLE 1

URINARY DHA AND OESTROGEN EXCRETION OF NORMAL AND GRYPTORCHID BOARS, FOLLOWING TREATMENT WITH HGG BEFORE AND AFTER RELOCATION OF THE TESTES

\begin{tabular}{|c|c|c|c|c|c|c|}
\hline $\begin{array}{c}\text { Boar } \\
\text { no. }\end{array}$ & $\begin{array}{l}\text { Cryptorchid } \\
\text { condition }\end{array}$ & $\begin{array}{c}\text { Age } \\
\text { (months) }\end{array}$ & Treatment & $\begin{array}{c}D H A \\
(m g / 24 h r)\end{array}$ & $\begin{array}{r}\text { Oestrogen } \\
(m g / 24 h r)\end{array}$ & $\begin{array}{l}\text { No. of } \\
\text { samples } \dagger\end{array}$ \\
\hline \multirow[t]{2}{*}{3487} & None & 7 & $\begin{array}{l}\text { Pretreatment } \\
2000 \text { i.u. HCG daily } \\
\text { Post treatment }\end{array}$ & $\begin{array}{c}8 \cdot 84 \pm 2 \cdot 66 \\
51 \cdot 78^{* *} \pm 12 \cdot 85 \\
31 \cdot 24^{* *} \pm 15 \cdot 01\end{array}$ & $\begin{array}{c}2 \cdot 87 \pm 1 \cdot 19 \\
18 \cdot 69^{* *} \pm 4 \cdot 71 \\
22 \cdot 52^{* *} \pm 11 \cdot 10\end{array}$ & $\begin{array}{l}5 \\
5 \\
5\end{array}$ \\
\hline & None & 29 & $\begin{array}{l}\text { Pretreatment } \\
2000 \text { i.u. HCG daily } \\
\text { Post treatment }\end{array}$ & $\begin{array}{l}14 \cdot 03 \pm 0 \cdot 49 \\
67 \cdot 85 * * \pm 15 \cdot 14 \\
12 \cdot 92 \pm 2 \cdot 88\end{array}$ & $\begin{array}{c}3.94 \pm 0.32 \\
16.96 * * \pm 5.51 \\
3.97 \pm 0.87\end{array}$ & $\begin{array}{l}5 \\
5 \\
5\end{array}$ \\
\hline \multirow[t]{3}{*}{3401} & None & 10 & $\begin{array}{l}\text { Pretreatment } \\
2000 \text { i.u. HCG daily } \\
\text { Post treatment }\end{array}$ & $\begin{array}{r}5 \cdot 04 \pm 0 \cdot 76 \\
47 \cdot 20^{* *} \pm 13 \cdot 47 \\
53 \cdot 74 * * \pm 26 \cdot 25\end{array}$ & $\begin{array}{c}0 \cdot 85 \pm 0 \cdot 11 \\
18 \cdot 15^{* *} \pm 5 \cdot 05 \\
22 \cdot 42^{* *} \pm 12 \cdot 70\end{array}$ & $\begin{array}{l}5 \\
5 \\
5\end{array}$ \\
\hline & & 10 & $\begin{array}{l}\text { Testes placed in } \\
\text { abdomen }\end{array}$ & & & \\
\hline & $\begin{array}{c}\text { Surgically } \\
\text { bilateral }\end{array}$ & 12 & $\begin{array}{l}\text { Pretreatment } \\
2000 \text { i.u. HCG daily } \\
\text { Post treatment }\end{array}$ & $\begin{array}{ll}72 \cdot 21 & \pm 5 \cdot 13 \\
83 \cdot 13 & \pm 12 \cdot 41 \\
76 \cdot 37 & \pm 16 \cdot 37 \\
\end{array}$ & $\begin{array}{cc}8 \cdot 24 & \pm 1 \cdot 09 \\
16 \cdot 04^{*} & \pm 2 \cdot 86 \\
12 \cdot 39 & \pm 2 \cdot 01\end{array}$ & $\begin{array}{l}5 \\
4 \\
4\end{array}$ \\
\hline \multirow[t]{3}{*}{3486} & None & 11 & $\begin{array}{l}\text { Pretreatment } \\
2000 \text { i.u. HCG daily } \\
\text { Post treatment }\end{array}$ & $\begin{array}{r}8.34 \pm 2.28 \\
26 \cdot 83^{* *} \pm 8.40 \\
82 \cdot 77^{* *} \pm 29 \cdot 89\end{array}$ & $\begin{array}{r}1 \cdot 80 \pm 0.68 \\
13 \cdot 13^{* *} \pm 8 \cdot 15 \\
37 \cdot 84^{* *} \pm 14 \cdot 66\end{array}$ & $\begin{array}{l}5 \\
4 \\
5\end{array}$ \\
\hline & & 11 & $\begin{array}{l}\text { Testes placed in } \\
\text { abdomen }\end{array}$ & & & \\
\hline & $\begin{array}{l}\text { Surgically } \\
\text { bilateral }\end{array}$ & 13 & $\begin{array}{l}\text { Pretreatment } \\
2000 \text { i.u. kicG daily } \\
\text { Post treatment }\end{array}$ & $\begin{array}{cc}9.71 & \pm 0.96 \\
18.07 * & \pm 2.64 \\
9 \cdot 18 & \pm 2.65\end{array}$ & $\begin{array}{ll}2.22 & \pm 0.44 \\
2.30 & \pm 0.36 \\
2 \cdot 41 & \pm 0.91\end{array}$ & $\begin{array}{l}5 \\
5 \\
5\end{array}$ \\
\hline \multirow[t]{3}{*}{3390} & Bilateral & 20 & $\begin{array}{l}\text { Pretreatment } \\
2000 \text { i.u. HCG daily } \\
\text { Post treatment }\end{array}$ & $\begin{array}{ll}9 \cdot 04 & \pm 1.40 \\
16 \cdot 02 * & \pm 2 \cdot 37 \\
17 \cdot 21 & \pm 8 \cdot 37\end{array}$ & $\begin{array}{l}3.25 \pm 0.17 \\
6.75^{*} \pm 0.91 \\
6.73 \pm 3.16\end{array}$ & $\begin{array}{l}5 \\
5 \\
5\end{array}$ \\
\hline & & 20 & $\begin{array}{l}\text { Testes placed in } \\
\text { flank }\end{array}$ & & & \\
\hline & $\begin{array}{c}\text { Testes out of } \\
\text { abdomen }\end{array}$ & 22 & $\begin{array}{l}\text { Pretreatment } \\
2000 \text { i.u. HCG daily } \\
\text { Post treatment }\end{array}$ & $\begin{array}{c}7 \cdot 13 \pm 1 \cdot 15 \\
24 \cdot 79^{* *} \pm 6 \cdot 23 \\
13 \cdot 42^{* *} \pm 1 \cdot 22\end{array}$ & $\begin{array}{l}2 \cdot 89 \pm 0.30 \\
8 \cdot 16^{* *} \pm 1 \cdot 64 \\
6 \cdot 88^{* *} \pm 0.42\end{array}$ & $\begin{array}{l}5 \\
5 \\
5\end{array}$ \\
\hline \multirow[t]{3}{*}{ C-17 } & Bilateral & 15 & $\begin{array}{l}\text { Pretreatment } \\
2000 \text { i.u. HCG daily } \\
\text { Post treatment }\end{array}$ & $\begin{array}{ll}17.94 & \pm 1.91 \\
32.66 & \pm 7.50 \\
22.89 & \pm \\
& \pm 16\end{array}$ & 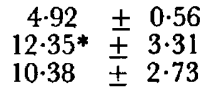 & $\begin{array}{l}5 \\
5 \\
5\end{array}$ \\
\hline & & 15 & $\begin{array}{l}\text { Testes placed in } \\
\text { flank }\end{array}$ & & & \\
\hline & $\begin{array}{c}\text { Testes out of } \\
\text { abdomen }\end{array}$ & 16 & $\begin{array}{l}\text { Pretreatment } \\
2000 \text { i.u. HCG daily } \\
\text { Post treatment }\end{array}$ & 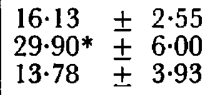 & $\begin{array}{cc}4 \cdot 70 & \pm 0.95 \\
14.56^{* *} \pm & 1 \cdot 38 \\
3.49 & \pm 1.00\end{array}$ & $\begin{array}{l}5 \\
5 \\
5\end{array}$ \\
\hline
\end{tabular}

Values for DHA and oestrogen expressed as means \pm S.E.

$* P<0.05 ; * * P<0.01$.

$\dagger$ 48-hr samples, except during HCG treatment when 24-hr samples were collected.

DHA and oestrogen during and following HCG treatment occurred in two normal boars $(3401,3486)$. Following placement of the scrotal testes in the abdomen, no significant rise in steroid excretion occurred when HCG was administered, with 
the exception of DHA excretion in one boar and oestrogen excretion in the other boar. In two bilaterally cryptorchid boars (3390, C-17), a limited increase in the urinary levels of DHA and oestrogen resulted from the administration of HCG. When the cryptorchid testes were placed outside of the abdominal cavity, however, a highly significant increase in urinary steroid levels was measured following the injection of HCG. For one boar, these high levels persisted during the post-treatment period.

The results suggest that normal and cryptorchid testes, when present in the abdominal cavity, have only a limited ability to respond to gonadotrophin stimulation by increasing steroid hormone production. Conversely, both normal and cryptorchid testes are able to respond to gonadotrophin stimulation by increased steroid production when they are in a position outside the abdomen. Hall (1965) has demonstrated with rabbit testis tissue that $\left[{ }^{14} \mathrm{C}\right]-1$-acetate incorporation into $\left[{ }^{14} \mathrm{C}\right.$ ] testosterone in vitro is less at $40^{\circ} \mathrm{C}$ than at $38^{\circ} \mathrm{C}$, suggesting that steroid biosynthesis is significantly lower at the abdominal temperature than at the scrotal temperature.

Although unilaterally and bilaterally cryptorchid boars are able to excrete levels of DHA and oestrogens which are comparable to those of normal boars (Liptrap \& Raeside, 1970), stimulation of further endocrine activity with endogenous or exogenous gonadotrophin is quite limited. The present results indicate that the limitation in response to gonadotrophin in the naturally cryptorchid animal may be due, at least in part, to the higher abdominal temperature. Presumably environmental factors, such as the abdominal temperature, are more important than genetic factors associated with cryptorchidism, in the limited endocrine response of the testis to gonadotrophin stimulation.

The authors wish to express thanks to Mrs P. Patterson and Mr P. McNally for their technical assistance. This research was supported by the Ontario Department of Agriculture and Food.

\section{REFERENCES}

FredeEn, H. T. \& Newman, J. A. (1968) Cryptorchid condition and selection for its incidence in Lacombe and Canadian Yorkshire pigs. Can. F. Anim. Sci. 48, 275.

HALL, P. F. (1965) Influence of temperature upon the biosynthesis of testosterone by rabbit testis in vitro. Endocrinology, 76, 396.

Huis in'T VeLd, L. G., Louwerens, B. \& Reilingh, W. (1961) Neutral 17-ketosteroids in porcine urine. Nature, Lond. 191, 175.

Liptrap, R. M. \& RAEside, J. I. (1970) Urinary steroid excretion in cryptorchidism in the pig. $\mathcal{F}$. Reprod. Fert. 21, 293.

Liptrap, R. M. \& RAEside, J. I. (1971) Urinary steroid excretion in response to endogenous and exogenous gonadotrphin stimulation of cryptorchid testes in the pig. F. Reprod. Fert. 25, 55.

RAEside, J. I. (1963) A procedure for the chemical determination of estrone and estradiol-17 $\beta$ in the urine of nonpregnant sows. Can. F. Biochem. Physiol. 41, 2013.

RAEside, J. I. (1965) Urinary excretion of dehydroepiandrosterone and oestrogens by the boar. Acta endocr., Copenh. 50, 611.

SNedecor, G. W. (1956) Statistical methods, p. 45. Iowa State University Press, Ames, Iowa. 